\title{
KEPEMIMPINAN KEPALA SEKOLAH DALAM MENGEMBANGKAN BUDAYA SEKOLAH EFEKTIF DI SEKOLAH DASAR
}

\author{
Mohammad Ali Ridho \\ Universitas Negeri Surabaya \\ mohammadridho@mhs.unesa.ac.id
}

\begin{abstract}
Abstrak: Kepemimpinan kepala sekolah memegang peranan penting dalam mengembangkan budaya sekolah efektif. Penelitian ini bertujuan untuk menganalisis gaya dan peran kepemimpianan kepala sekolah dalam upaya mengembangkan budaya sekolah efektif. Jenis penelitian ini adalah studi kasus yang dilakukan di SD Plus Nurul Hikmah Pamekasan. Teknik pengumpulan data yang digunakan adalah wawancara, observasi dan dokumentasi. Teknik analisis data yang digunakan adalah: (1) reduksi data; (2) penyajian data; dan (3) kesimpulan. Uji keabsahan data diuji melalui: (1) credibility; (2) transferability; (3) dependability; (4) confirmability. Hasil penelitian ini menunjukkan bahwa (1) kepala sekolah tidak hanya menerapkan salah satu gaya kepemimpinan tertentu, tetapi sesuai kondisi yang dihadapi. (2) Peran kepala sekolah dalam mengembangkan budaya sekolah efektif adalah sebagai edukator, manajer, administrator, supervisor, leader, inovator dan motivator. (2) Upaya kepala sekolah dalam mengembangkan budaya sekolah efektif adalah: (a) Mengembangkan hubungan harmonis diantara semua komponen sekolah, (b) Mengembangkan keamanan sekolah, (c) Mengembangkan lingkungan sekolah yang kondusif untuk belajar.
\end{abstract}

Kata kunci: Kepemimpinan Kepala Sekolah, Pengembangan Budaya Sekolah, sekolah efektif.

Abstract: Headmaster's Leadership plays an important role in developing an effective school culture. This study aims to analyze the style and role of principal leadership in an effort to develop an effective school culture. This type of research is a case study conducted at SD Plus Nurul Hikmah Pamekasan. Data collection techniques used were interviews, observation and documentation. Data analysis techniques used are: (1) data reduction; (2) presentation of data; And (3) conclusions. Test the validity of the data through the test: (1) credibility; (2) transferability; (3) dependability; (4) confirmability. The results of this study indicate that (1) the principal does not only apply one particular leadership style, but according to the conditions at hand. (2) The role of the principal in developing an effective school culture is as an educator, manager, administrator, supervisor, leader, innovator and motivator. (2) The Headmaster's efforts in developing an effective school culture are: (a) Developing harmonious relationships among all school components, (b) Developing school security, (c) Developing a school environment conducive to learning.

Keywords: Headmaster's Leadership; Development of School Culture; Effective School.

Era reformasi memberikan tantangan yang cukup signifikan dalam berbagai dimensi kehidupan bangsa. Agenda kebangsaan kita seolah dipaksa untuk merespon berbagai tantangan reformasi yang oleh pemerintah dimaknai sebagai kompetisi, salah satunya pendidikan. Dalam sudut pandang positif, hal ini berdampak pada peningkatan pengelolaan lembaga pendidikan sebagai syarat mutlak untuk menjaga eksistensinya dalam arus deras kompetisi institusional. Hal ini juga sejalan dengan harapan dan tuntutan masyarakat yang semakin selektif terhadap pemilihan mutu sekolah. Berbicara tentang mutu, pendidikan di Indonesia sampai saat ini belum begitu menggembirakan. Salah satu indikator ditunjukkan oleh hasil survey Program for International Student Assessment (PISA) tahun 2015 sebagaimana dikutip dari Herviana, dkk (2016:237) yang menempatkan Indonesia berada di urutan ke 
69 dari 76 negara. Demikian juga dalam indeks pembangunan manusia (IPM) sebagaimana dirilis United Nations Development Programme (UNDP) tahun 2016 menunjukkan bahwa Indonesia berada urutan 113 dari 188 negara. Keberhasilan tujuan pendidikan di sekolah tergantung pada sumber-daya manusia yang ada di sekolah tersebut yaitu kepala sekolah, guru, siswa, pegawai tata usaha, dan tenaga kependidikan lainnya (Hasmayati, Masalah, \& Selatan, 2011). Dalam menciptakan sumber daya manusia yang berkualitas guru berada pada baris terdepan, karena guru langsung berhadapan dengan peserta didik dalam penyampaian proses pembelajaran (Tabularasa \& Unimed, 2011). Agar proses pendidikan sekolah dengan baik, tentunya diperlukan tenaga - tenaga pengajar yang berkualitas, memiliki loyalitas serta disiplin yang tinggi (Purwanti, 2013). Mencerdaskan kehidupan bangsa merupakan tujuan ideal untuk direalisasikan melalui sistem pendidikan nasional (Nasution, 2015).

Berkaca pada hasil survey ini, peningkatan mutu pendidikan tidak bisa ditawar lagi dan menjadi sebuah keniscayaan untuk menjaga eksistensi sekolah dalam kontestasi pendidikan secara global. Dengan demikian, peningkatan mutu sekolah menjadi prioritas utama bagi pengelola sekolah, salah satunya melalui reformasi sekolah. Mulyasa (2002:144-145) menyatakan tentang perlunya peningkatan mutu pendidikan melalui reformasi sekolah. Reformasi sekolah dilakukan dengan mempertimbangkan perkembangan ilmu pengetahuan dan teknologi berpengaruh besar terhadap sistem pendidikan di sekolah; perkembangan penduduk yang cepat membutuhkan pelayanan pendidikan yang besar; sumberdaya manusia yang berkualitas merupakan tantangan bagi sekolah untuk menghasilkan lulusan yang berkualitas; dan perkembangan teknologi informasi yang cepat berdampak pada dunia pendidikan.

Sebagai konsekwensi logis dari pentingnya sebuah reformasi sekolah, belakangan ini banyak muncul ide-ide kreatif dan inovatif persekolahan modern dengan berbagai nama seperti sekolah unggul, sekolah terpadu, sekolah percontohan, dan lain sebagainya. Beberapa negara maju menyebut gerakan ini dengan nama sekolah efektif. Menurut Sagala (2010: 81) keefektifan sekolah (effective schooling) dan sekolah yang bermutu (school quality) merupakan wacana yang tak kunjung habishabisnya sepanjang sekolah itu masih menjalankan kegiatannya, artinya seiring dengan tuntunan akan perubahan yang terus menerus mengikuti perkembangan zaman melalui perkembangan ilmu pengetahuan dan teknologi (IPTEK), tuntutan akan keefektifan dan mutu sekolah mengiringinya.

Aan Komariyah (2005:7) mendefinisikan efektifitas sebagai ukuran yang menyatakan sejauh mana sasaran/tujuan telah dicapai. Dengan demikian dapat dinyatakan bahwa sekolah efektif adalah sekolah yang menunjukkan kesesuaian antara hasil yang dicapai dengan hasil yang diharapkan. Ciri utama sekolah efektif, berdasarkan berbagai riset meliputi: (a) kepemimpinan instruksional yang kuat; (b) harapan yang tinggi terhadap prestasi siswa; (c) adanya lingkungan belajar yang tertib dan nyaman; (d) menekankan kepada keterampilan dasar; (e) pemantauan secara kontinyu terhadap kemajuan siswa; dan (f) terumuskan tujuan sekolah secara jelas (Davis \& Thomas, 1989: 12).

Lebih sederhana, Depdiknas (2003:10) menyebutkan bahwa sekolah sebagai sistem memiliki tiga aspek pokok yang erat kaitanya dengan sekolah efektif, yakni proses belajar mengajar, kepemimpinan dan manajemen sekolah serta budaya sekolah. Selama ini program aksi untuk meningkatakan keefektifan sekolah kurang menyentuh aspek budaya. Keberhasilan sebuah lembaga pendidikan tidak hanya didukung oleh perlengkapan sarana prasarana, tenaga pendidik yang berkualitas ataupun input siswa yang baik, tetapi budaya sekolah sangat berperan terhadap peningkatan keefektifan sekolah. Menurut Mayer dan Rowen (dalam Jamaluddin, 2002:24) budaya sekolah merupakan jiwa (spirit) sebuah sekolah yang memberikan makna terhadap kegiatan kependidikan sekolah tersebut, jika budaya sekolah lemah, maka ia tidak kondusif bagi pembentukan sekolah efektif. Sebaliknya budaya sekolah kuat maka akan menjadi fasilitator bagi peningkatan sekolah efektif. Pidarta (2000:162) juga menyatakan bahwa budaya sekolah sangat berpengaruh dalam pembentukan sekolah yang efektif. 
Sekolah sebagai suatu bentuk organisasi punya budaya tersendiri yang membentuk corak dari sistem yang utuh dan khas. Kekhasan budaya sekolah tidak lepas dari visi dan proses pendidikan yang berlangsung yang menuntut keberadaan unsur-unsur atau komponen-komponen sekolah sebagai bidang garapan organisasi. Unsur-unsur tersebut saling berinteraksi dan memiliki keterkaitan antara satu dengan yang lain, dan adakalanya suatu budaya bisa dipakai terus, juga adakalanya harus diperbaiki dan juga adakalanya harus dibuang untuk diganti dengan budaya baru.

Budaya sebagiamana dikemukakan Peterson (1998:28) adalah hal-hal yang berhubungan dengan norma-norma, nilainilai, kepercayaan, tradisi, upacara-upacara yang dibangun atas hasil kerjasama sekelompok orang. Zamroni (dalam Widodo, 2005:11) mendeskripsikan budaya sekolah sebagai pola nilai-nilai, norma-norma, sikap, ritual, mitos, dan kebisaaan-kebisaaan yang dibentuk dalam perjalanan panjang sekolah.

Hampir semua sekolah memiliki serangkaian atau seperangkat keyakinan, nilai, norma, dan kebisaaan yang menjadi ciri khasnya dan senantiasa disosialisasikan dan ditransmisikan melalui berbagai media. Dengan berjalannya waktu, proses tersebut telah membentuk suatu iklim budaya tertentu dalam lingkungan sekolah. Iklim tersebut secara langsung menggambarkan perasaanperasaan, dan pengalaman-pengalaman moral yang ada di sekolah. Budaya sekolah sekali lagi menunjukkan kompleksitas unsur keyakinan, nilai, norma, kebisaaan, bahasa, dan tujuan-tujuan apa pun yang lebih baik.

Budaya sekolah memiliki peranan penting dalam menciptakan sekolah yang efektif, yang mampu mencapai tujuan dan berbagai sasaran. Budaya sekolah akan menumbuhkan perasaan dalam diri warga sekolah tentang bagaimana berperilaku, apa yang harus dilakukan, dan menentukan skala prioritas tugas. Perlunya pembentukan budaya belajar sepanjang hayat (lifelong learning), yaitu kemampuan untuk mengetahui bagaimana belajar yang membekali kemampuan bertahan dan bersaing di setiap perubahan yang dihadapi (Sudarya, Suratno, \& Indonesia, 2002). Keberadaan budaya sekolah juga memberikan warna terhadap cara-cara penyelesaian masalah yang muncul dalam menentukan cara yang tepat untuk melayani stakeholder pendidikan dan mengidentifikasi reaksi yang tepat dalam mengantisipasi kompetisi yang dinamis. Budaya sekolah yang efektif akan mendorong semua warga sekolah untuk bekerjasama yang didasarkan saling percaya, mengundang partisipasi seluruh warga, mendorong munculnya gagasan-gagasan baru, dan memberikan kesempatan untuk terlaksananya pembaharuan di sekolah yang semuanya ini bermuara pada pencapaian hasil terbaik.

Selama ini, perbaikan yang cenderung bersifat konvensional juga dikeluhkan Sumarni (2005, para. 6) yang menyatakan bahwa program aksi untuk peningkatan kualitas sekolah secara konvensional senantiasa bertumpu pada peningkatan kualitas proses belajar mengajar (PBM), sedikit menyentuh aspek kepemimpinan dan manajemen serta kurang menyentuh aspek budaya sekolah. Hal ini sangat disayangkan, padahal budaya sekolah yang baik dapat mendukukung terwujudnya keefektifan di sekolah, seperti misalnya budaya yang selalu mendukung keunggulan, budaya prestasi, budaya kedisiplinan, budaya kebersamaan, budaya baca, budaya hidup sehat, dan budaya-budaya lainnya yang berorientasi pada kualitas dan peningkatan pendidikan yang lebih efektif.

Pengembangan budaya sekolah efektif tidak akan pernah berhasil secara maksimal tanpa kepemimpinan kepala sekolah yang berkualitas. Tantangan kepala sekolah adalah di dalam budaya organisasi sekolah terdapat sub budaya "The influence culture has on members of an organisation varies, and there are often several sub-cultures in an organization" (Leo \& Wickenberg, 2013). Kepemimpinan yang baik apabila mendukung tiga hal "personal support, technical support, and cultural support" (Sun, Przybylski, \& Johnson, 2016). "Both teachers and principals play a key role in determining the success of learning process" (Yuen, Lee, \& Law, 2009). Hauge juga menyatakan bahwa "[rincipal needs to develop shared and collaborative conceptions of leadership in schools" (Hauge \& Norenes, 2014). Kepemimpinan menurut pandangan Thoha (2006:5) adalah aktivitas untuk mempengaruhi orang-orang supaya diarahkan untuk mencapai tujuan organisasi. Kualitas kepemimpinan di 
sekolah mempunyai peran penting dalam upaya meningkatkan kualitas dan keefektifan sekolah. Sergiovanni (dalam Owens, 1995:13), menjelaskan sebagai berikut.

$$
\text { ...of cuorse educational }
$$
organization are more complex for effectivness to be attributed to any single dimension. Nev-ertheles, leadership quality owens a fair share of responsibility for effectivness. Unlike other factors beyond the control of the school...the nature and quality of leadership seem readily (amenable) to...improvement.

Dalam pandangan sergiovanni tersebut dapat digaris bawahi bahwa kualitas kepemimpinan sekolah menjadi faktor utama dari banyak faktor yang mengarah pada efektifitas dan perbaikan sekolah. Kepemimpinan pendidikan sebagai satu kemampuan dan proses memengaruhi, mengkoordi nasi, dan menggerakkan orang atau kelompok lain yang ada hubungan nya dengan pengembangan ilmu pengetahuan dan pelaksanaan pendidikan dan pengajaran (Gunawan, Administrasi, Fakultas, Pendidikan, \& Malang, n.d.). Dalam kepemimpinan sekolah berlangsung sebuah interaksi baik sifatnya individual atau kelompok (siswa, guru, kepala sekolah, orang tua, masyarakat, dan karyawan). Dan muara besar (the grand ending) dari interaksi ini yaitu terbentuknya budaya organisasi sekolah yang kuat sehingga pendidikan dapat berlangsung dengan efektif dan efesien. Itulah sebabnya kepemimpinan kepala sekolah sangat penting artinya bagi terwujudnya organisasi sekolah yang efektif.

Namun, faktanya memimpin sekolah sebagai sebuah organisasi tidaklah mudah. Seorang kepala sekolah dituntut untuk menyesuaikan prilaku dan gaya kepemimpinan yang sesuai dan cocok bagi setiap bawahannya. Rivai (2014:42) menyatakan gaya kepemimpinan adalah sekumpulan ciri yang digunakan pimpinan untuk memengaruhi bawahan agar sasaran organisasi tercapai atau dapat pula dikatakan bahwa gaya kepemimpinan adalah pola perilaku dan strategi yang disukai dan sering diterapkan oleh seorang pemimpin.
Selain gaya kepemimpinan, dalam membangun budaya sekolah yang efektif kepala sekolah juga dituntut untuk selalu meningkatkan perannya sebagai pemimpin di linkungan sekolah. kaitannya dengan peran, menurut kementrian pendidikan dan kebudayaan, kepala sekolah dikatakan mempunyai efektifitas kepemimpinan yang tinggi apabila kepala sekolah mampu melaksanakan perannya sebagai educator, manajer, administrator dan supervisor (EMAS). Dalam perkembangan selanjutnya, sesuai dengan kebutuhan masyarakat dan perkembangan zaman, maka kepala sekolah juga harus mampu berperan sebagai leader, innovator dan motivator di sekolahnya. Dengan demikian dalam paradigma baru manajemen pendidikan kepala sekolah yang efektif sedikitnya harus mampu berfungsi sebagai educator, manager, administrator, supervisor, leader, innovator dan motivator (EMASLIM) (Mulyasa, 2003:98).

Efektifitas peran kepemimpinan kepala sekolah yang maksimal memberikan pengaruh yang cukup besar dalam upaya mengembangkan budaya sekolah untuk mewujudkan keefektifan sekolah (Ekosiswoyo, n.d.). Keefektifan sekolah menuntut perubahan sikap dan tingkah laku dari seluruh komponen sekolah, baik kepala sekolah, guru maupun staf tata usaha, termasuk orang tua siswa dan masyarakat dalam memandang, memahami dan membantu sekaligus memonitoring dan mengevaluasi dalam pelaksanaan sekolah (Sudharta, Mujiati, Rosidah, Gunawan, \& Malang, n.d.). Kualitas belajar siswa serta para lulusan banyak ditentukan oleh keberhasilan pelaksanaan PBM tersebut atau dengan kata lain banyak ditentukan oleh fungsi dan peran guru yang tak lepas dari penciptaan budaya sekolah oleh kepala sekolah (Surjana, n.d.). "Setting a good example or serving as a good role model is an important part of exercising leadership" dimana pemimpin memegang peranan penting (Walker, Truong, Kong, \& Tri, 2015). Juga diungkapkan oleh $\mathrm{Ng}$ bahwa "School leadership is an important factor in educational reform and school transformation" ( $\mathrm{Ng}, 2012)$. "Rather than focusing just on the leader or on the follower, transformational leadership examines the relationship between leader and follower and considers that by engaging the higher needs 
of the followers, " (Chin, 2007). Pemimpin yang berhasil adalah pemimpin yang mau mempraktikan kepemimpinannya "Successful school leaders can create change in schools based on a synthesis of ideas informed by theory but developed primarily through practice" (Somprach, Ngang, \& Popoonsak, 2017). Hal ini menjadi daya tarik bagi penulis untuk melakukan penelitian di lapangan tentang bagaimana kepemimpinan kepala sekolah dalam upaya mengembangkan budaya sekolah dalam rangka mewujudkan keefektifan sekolah. Penelitian ini dilakukan di Sekolah Dasar Plus Nurul Hikmah Pamekasan.

SD Plus Nurul Hikmah Pamekasan merupakan lembaga pendidikan swasta yang menjadi salah satu rujukan dan tergolong sebagai sekolah favorit di daerah pamekasan, indikasinya dapat dilihat dari kepercayaan masyarakat dalam memilih sekolah ini sebagai tempat belajar bagi anak-anaknya. Secara kultur, SD Plus Nurul Hikmah Pamekasan adalah sekolah yang bernuansa islami, internalisasi nilai-nilai islami dalam sebuah program pembiasaan dan pembudayaan yang menjadi ciri khas dalam sekolah ini. Diantaranya budaya sholat berjamaah, budaya 5S, tahfidz juz 30, berdo'a, dan lain sebagainya. Selain itu, SD Plus Nurul Hikmah Pamekasan membudayakan nilai-nilai positif yang mendukung terwujudnya keefektifan sekolah, diantaranya adalah budaya disiplin, budaya jujur, budaya baca, budaya hidup bersih, tertib dan aman, budaya berprestasi dan lain sejenisnya. Hal ini sejalan dengan kultur sosial masyarakat pamekasan yang agamis sehingga sekolah ini bisa diterima dan survive di kalangan masyarakat Pamekasan. Pencapaian ini tidak lepas dari peran kepala sekolah dalam mengembangkan budaya sekolah efektif di sekolah ini.

Berdasarkan studi pendahuluan, kepala sekolah SD Plus Nurul Hikmah Pamekasan memiliki peran yang cukup vital di sekolah. Salah satu perannya adalah sosok kepala sekolah yang secara personal dikenal dengan sosok yang penyabar dan baik, hal ini menjadi modal kepala sekolah dalam menjalankan roda kepemimpinannya di sekolah khususnya dalam menjalin hubungan yang harmonis dengan seluruh warga sekolah. Selain itu, kepala sekolah memerankan fungsinya sebagai educator yang selalu disiplin dan menanamkan nilainilai akhlak kepada peserta didik. Kepala sekolah juga sebagai manajer yang selalu mengatur, mengelola, memimpin, monitoring setiap program kegiatan khususnya program pembiasaan dan pembudayaan nilai-nilai positif.

Kepala sekolah SD Plus Nurul Hikmah Pamekasan juga memerankan fungsinya sebagai administrator yang tertib administratif dalam semua bidang. Kepala sekolah juga sebagai supervisor yang selalu melakukan supervisi terhadap guru secara rutin dalam satu bulan untuk pembinaan dan peningkatan profesionalisme guru. Kepala sekolah juga menjalankan fungsinya sebagai leader yang selalu mengawal program kebijakan sekolah dengan baik, dan juga sebagai inovator yang selalu memberikan ide pembaharuan yang kreatif dan inovatif khususnya dalam membangun budaya sekolah yang efektif. Kepala sekolah juga memerankan fungsinya sebagai motivator yang selalu memotivasi guru dan staf lainnya untuk selalu berkembang khususnya dalam melaksanakan tugasnya masingmasing.

Dalam menjalankan roda epemimpinan, kepala sekolah SD Plus Nurul Hikmah Pamekasan menggunakan model kepemimpinan spiritual (Spritual leadership). Kepemimpinan yang berbasis spiritualitas, kepemimpinan yang mengedepankan moralitas, kepekaan, etika dalam berinteraksi dengan orang lain khususnya dengan staf dan bawahan. Kepemimpinan spiritual disebut juga sebagai kepemimpinan yang berdasarkan etika religius, kepemimpinan yang mampu mengilhami, membangkitkan, mempengaruhi dan menggerakkan melalui keteladanan, pelayanan, kasih sayang dan implementasi nilai dan sifat-sifat ketuhanan lainnya dalam tujuan, proses, budaya dan perilaku kepemimpinan.

Nilai-nilai spiritual dijadikan kepala sekolah SD Plus Nurul Hikmah Pamekasan sebagai motivasi dalam menjalankan roda kepemimpinan. Pendekatan kepemimpinan spiritual ini digunakan kepala sekolah dalam berinteraksi dan membangun hubungan dengan warga yang berada di lingkungan sekolah sehingga terbangun hubungan yang baik antara kepala sekolah dengan guru dan 
staf yang berada di lingkungan sekolah. Hal ini menjadi poin Plus dalam kepemimpinan kepala sekolah untuk mengembangkan dan memajukan sekolah sehingga terwujud sekolah yang efektif. Secara umum pendekatan ini berhasil mengantarkan SD Plus Nurul Hikmah Pamekasan menjadi sekolah yang berprestasi sebagaimana tercermin dalam beberapa capaian dan prestasi yang diraih SD Plus Nurul Hikmah baik akademik maupun non akademik.

Berdasarkan uraian diatas, penulis tertarik untuk meneliti bagaimana gaya dan peran kepemimpinan kepala sekolah dalam upaya mengembangkan budaya sekolah efektif di SD Plus Nurul Hikmah Pamekasan. Adapun judul penelitian ini secara redaksional adalah "Kepemimpinan Kepala Sekolah dalam Mengembangkan Budaya Sekolah Efektif (Studi Kasus di SD Plus Nurul Hikmah Pamekasan)".

\section{METODE}

Pendekatan penelitian yang digunakan dalam penelitian ini adalah pendekatan kualitatif (qualitative research). Adapun jenis penelitian ini adalah studi kasus (Case Study). K.Yin (2000:18) mendifinisikan studi kasus sebagai suatu inkuiri empiris yang menyelidiki fenomena di dalam konteks kehidupan nyata, bilamana batas-batas antara fenomena dan konteks tak tampak dengan tegas, dan dimana multi sumber bukti dimanfaatkan. Penelitian kualitatif dengan metode studi kasus yang digunakan dalam penelitian ini bertujun untuk memahami tentang kepemimpinan kepala sekolah dalam mengembangkan budaya sekolah yang efektif di SD Plus Nurul Hikmah Pamekasan.

Secara sederhana, desain penelitian dalam penelitian ini diuraikan sebagai berikut, (1) melakukan studi penelitian (2) memotret fokus-fokus yang telah ditetapkan sebelumnya yaitu gaya kepemimpinan, budaya sekolah, peran kepala sekolah dalam mengembangkan budaya sekolah efektif, keefektifan sekolah di SD Plus Nurul Hikmah Pamekasan. mendokumentasikan upaya-upaya yang dilakukan kepala sekolah dalam mengembangkan budaya sekolah efektif. (4) melakukan analisis dan membandingkan dengan teori dan standar yang baik dan ideal. (5) menarik simpulan dan memberi saran/usulan terutama terhadap fokus-fokus yang belum terlaksana dengan baik sesuai dengan teori, konsep dan standar.

Penelitan ini dilaksanakan di SD Plus Nurul Hikmah Pamekasan. Pemilihan ini didasarkan atas pertimbangan bahwa lembaga pendidikan SD Plus Nurul Hikmah Pamekasan termasuk lembaga pendidikan islam swasta yang tergolong sekolah unggulan dan berani bersaing di tingkat kabupaten Pamekasan, sehingga menjadi rujukan dan referensi yang diminati masyarakat kabupaten pamekasan baik masyarakat kota maupun masyarakat desa untuk menyekolahkan anaknya di sekolah ini. SD Plus Nurul Hikmah juga tergolong sekolah yang berprestasi baik bidang akademik maupun non akademik.

Dalam penelitian ini peneliti menggunakan teknik purposive sampling dan snowball sampling. Dalam penelitian ini yang menjadi subyek penelitian adalah kepala sekolah SD Plus Nurul Hikmah, Wakil Kepala, Guru, wali murid, siswa-siswi, Komite sekolah.

Teknik pengumpulan data yang digunakan dalam penelitian ini secara umum ada empat sebagaimana dipaparkan Sugiyono (2015:309), yaitu observasi partisipan, wawancara mendalam, studi dokumentasi, dan gabungan/triangulasi.

Untuk menguji keabsahan data peneliti menggunakan empat tipe standar atau kriteria utama untuk menjamin keterpercayaan hasil penelitian kualitatif sebagaiamana dipaparkan Moleong (2004:173) bahwa pengecekan data dilakukan dengan mendasarkan pada empat kriteria, yakni derajat kepercayaan (credibility), keteralihan (transferability), kebergantungan (dependability), kepastian (confirmability)".

Adapun teknik analisis data yang digunakan dalam penelitian ini adalah teknik analisis deskriptif dengan menempuh tiga langkah sebagaimana disampaikan Miles, Huberman dan Saldana (2014:31) meliputi: Pengumpulan Data, Kondensasi Data, Data Penyajian Data, dan Penarikan Kesimpulan. 


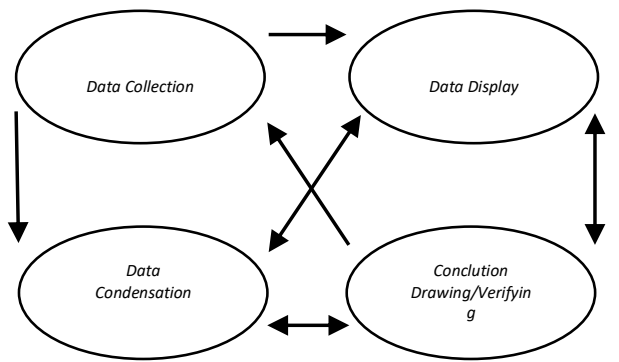

Gambar 1 Komponen-komponen Analisis Data Sumber: Miles, Huberman dan Saldana (2014:33)

Adapun langkah-langkah analisis data dalam penelitian ini adalah sebagai berikut:

\section{Pengumpulan Data (Data Collection)}

Pengumpulan data merupakan bagian integral dari kegiatan analisis data. Kegiatan pengumpulan data pada penelitian ini adalah dengan menggunakan cara observasi, wawancara dan studi dokumentasi. Kumpulan data tentang kepemimpinan kepala sekolah dalam mengembangkan budaya sekolah efektif yang diperoleh secara deskriptif merupakan catatan apa yang dilihat, diamati, disaksikan, dan dialami sendiri oleh peneliti.

\section{Kondensasi Data (Data Condensation)}

Data yang diperoleh di SD Plus Nurul Hikmah Pamekasan cukup banyak, untuk itu maka perlu segera dibutuhkan analisis data dengan teknik kondensasi. Kondensasi data ini peneliti gunakan untuk menyederhanakan data yang diperoleh dari SD Plus Nurul Hikmah Pamekasan, penyederhanaan ini dilakukan setelah data diperoleh lalu dirangkum dan diambil bagian-bagian penting yang ada kaitannya dengan fokus penelitian.

\section{Display Data (Display data)}

Setelah data dikondensasi, maka langkah selanjutnya adalah menyajikan data. Display atau penyajian data merupakan proses menampilkan data secara sederhana dalam bentuk kata-kata, kalimat, naratif, tabel, maktrik, dan grafik. Dalam penelitian ini, peneliti menyajikan data dalam bentuk kata-kata, kalimat, naratif, tabel atau matrik. Penyajian data yang demikian tersebut akan memberikan gambaran yang komprehensif, terorganisasikan, tersusun dalam pola hubungan hingga mudah dipahami.

\section{Verifikasi dan Penegasan Kesimpulan (Conclution Drawing and Verification).}

Penarikan simpulan merupakan kegiatan akhir dari analisis data. Simpulan ini dibuktikan dengan menafsirkan berdasarkan kategori yang ada dan menggabungkan dengan melihat hubungan antar data sehingga dapat diketahui secara menyeluruh tentang kepemimpinan kepala sekolah dalam mengembangkan budaya sekolah efektif di SD Plus Nurul Hikmah Pamekasan.

\section{PEMBAHASAN HASIL PENELITIAN Gaya Kepemimpinan Kepala Sekolah}

Berdasarkan data hasil penelitian, kepala sekolah SD Plus Nurul Hikmah Pamekasan tidak menerapkan satu gaya kepemimpinan tertentu, gaya kepemimpinan kepala sekolah bersifat kondisional tergantung pada situasi dan kondisi yang dihadapi. Gaya kepemimpinan kepala sekolah tercermin pada prilaku kepala sekolah dalam menjalankan tugasnya sehari-hari. Dalam realisasi programprogram sekolah misalnya, kepala sekolah tidak hanya berada di belakang layar (behind the scene) saja tetapi kepala sekolah menjadi pioneer dengan selalu terlibat aktif dalam program dan agenda yang dilaksanakan sekolah khususnya dalam upaya membangun budaya sekolah efektif.

Misalnya dalam membiasakan budaya disiplin, kepala sekolah berpartisipasi aktif dengan berusaha untuk hadir tepat waktu untuk menjadi teladan bagi semua komponen di lingkungan sekolah. Hal ini dilakukan kepala sekolah juga untuk menumbuhkan sikap partisipatif semua komponen sekolah dalam melaksanakan program-program sekolah.

Ditinjau dari situasi di atas, kepala sekolah SD Plus Nurul Hikmah Pamekasan menerapkan gaya kepemimpinan partisipatif. Hal ini sesuai dengan pendapat Hasibuan (2007:170) yang memaparkan bahwa kepemimpinan partisipatif adalah apabila dalam kepemimpinannya dilakukan dengan cara persuasif, menciptakan kerja sama yang serasi, menumbuhkan loyalitas, dan partisipasi para bawahan. Penerapan gaya 
kepemimpinan partisipatif oleh kepala sekolah SD Plus Nurul Hikmah Pamekasan ini menjadikan kepala sekolah mempunyai hubungan yang dekat dan seakan tidak ada sekat dengan bawahan, hal ini menjadi poin plus bagi kepala sekolah dalam membangun kerja sama yang baik dengan seluruh komponen sekolah.

Kepemimpinan partisipatif kepala sekolah ini membenarkan pernyataan Thoha (2003:42) bahwa dalam kepemimpinan partisipatif ini, pemimpin berusaha meminta dan mempergunakan saran-saran dan masukan dari para bawahannya, namun pengambilan keputusan masih tetap berada padanya. Dengan penerapan gaya kepemimpinan partisipatif ini akan membangun sebuah asumsi bahwa tidak ada suatu hal yang sulit dan tidak ada alasan untuk tidak bekerja, sehingga akan terbangun budaya kerja sama yang erat melalui pemberdayaan bawahan dalam hal ini guru dan karyawan dalam melaksanakan program sekolah.

Pemberdayaan mengindikasikan bahwa kepala sekolah tidak mengerjakan programprogram sendiri tetapi didelegasikan kepada bawahan sesuai dengan tugas masingmasing, hal ini dapat mengeliminer sebuah paradoks atau asumsi bahwa kepala sekolah sebagai one man show dalam suksesi program-program sekolah. Dalam situasi seperti ini menunjukkan bahwa kepala sekolah SD Plus Nurul Hikmah Pamekasan menerapkan gaya kepemimpinan delegatif sebagaimana disampaikan Hasibuan (2007:170) bahwa kepemimpinan delegatif apabila seorang pemimpin mendelegasikan wewenangnya kepada bawahan dengan lengkap. Dengan demikian, bawahan dapat mengambil keputusan dan kebijaksanaan dengan bebas atau leluasa dalam melaksanakan pekerjaannya.

\section{Dalam} menerapkan

gaya kepemimpinan delegatif kepala sekolah SD Plus Nurul Hikmah Pamekasan memberikan kesempatan yang luas kepada setiap lapisan baik guru, karyawan dan staf lainnya untuk menyalurkan kreatifitas dan inovasinya dalam upaya mengembangkan kemampuan profesionalnya. Kepala sekolah juga memberikan tugas dan wewenang yang jelas kepada bawahannya sesuai tugas pokok dan fungsinya (tupoksi) yang tertuang dalam job description masing-masing. Hal tersebut tercermin secara struktural-formal, kepala sekolah SD Plus Nurul Hikmah Pamekasan membagi tugas dan wewenangnya kepada enam wakil kepala sekolah yang berfungsi sebagai kepala urusan (Ka.Ur), kepala urusan tata usaha, kepala urusan kurikulum, kepala urusan kesiswaan, kepala urusan keuangan, kepala urusan sarana dan prasarana dan kepala urusan hubungan masyarakat (humas).

Pendelegasian tugas ini juga berarti pemberdayaan terhadap bawahan yang dapat bermanfaat untuk peningkatan kinerja menjadi lebih baik, menurut Mulyasa (2012:40) manfaat pemberdayaan ini juga dapat meningkatkan kecakapan-kecakapan penting pada saat menjalankan tugasnya, dan memberi rasa berprestasi yang lebih besar kepada staf sehingga dapat meningkatkan motivasi kerja.

Dalam situasi dan kondisi tertentu, kepala sekolah SD Plus Nurul Hikmah Pamekasan juga menerapkan gaya kepemimpinan otoriter. Menurut Hasibuan (2007:170) kepemimpinan otoriter adalah jika kekuasaan atau wewenang, sebagian besar mutlak tetap berada pada pimpinan atau kalau pimpinan itu menganut sistem sentralisasi wewenang.

Gaya kepemimpinan otoriter ini diterapkan kepala sekolah SD Plus Nurul Hikmah Pamekasan dalam situasi yang mendesak dan sifatnya penting untuk segara dilaksanakan atau dieksekusi. Misalnya, dalam pengumpulan tugas dari Dinas Pendidikan yang telah dideadline, kepala sekolah tidak berkompromi untuk tugastugas yang di beri tenggang waktu tertentu, bahkan kepala sekolah dapat memberikan reward dan punishment yang berat sebagai konsekwensi bagi mereka yang terlambat. Gaya kepemimpinan otoriter ini jarang dilakukan oleh kepala sekolah selama situasi dan kondisi dalam keadaan stabil.

Berdasarkan paparan data dan temuan penelitian yang dikorelasikan dengan teori dan didiskusikan secara mendalam dapat disimpulkan bahwa kepala sekolah SD Plus Nurul Hikmah Pamekasan tidak hanya menerapkan satu gaya kepemimpinan tertentu saja, tetapi lebih kondisional dan situasional. Hal ini berarti bahwa situasilah yang mungkin menentukan gaya apa yang digunakan. Tetapi dari ketiga gaya 
kepemimpinan tersebut di atas, yang paling dominan dalam kepemimpinan kepala sekolah SD Plus Nurul Hikmah Pamekasan adalah gaya partisipatif. Hal ini dapat menunjang pengembangan budaya sekolah sebagaimana dikemukakan Fullan (2001) yang menyatakan bahwa kepala sekolah hendaknya menegakkan lima prinsip dalam mengembanghkan budaya organisasi yang salah satu prinsipnya adalah menerapkan kepemimpinan partisipatif.

\section{Peran Kepemimpinan Kepala Sekolah dalam Mengembangkan Budaya Sekolah Efektif.}

Kepala sekolah SD Plus Nurul Hikmah Pamekasan sebagai pemimpin dalam institusi sekolah mempunyai peran yang sangat vital dalam upaya mewujudkan sekolah yang efektif. Upaya yang dilakukan kepala sekolah untuk mencapai keefektifan tersebut adalah mengembangkan budaya sekolah efektif yang sekaligus menjadi ciri khas dan brand bagi SD Plus Nurul Hikmah Pamekasan. Upaya kepala sekolah ini sejalan dengan pandangan Reynolds (dalam Mulyasa, 2013:90) bahwa dalam sekolah efektif, perhatian khusus diberikan kepada penciptaan dan pemeliharaan iklim dan budaya yang kondusif untuk belajar.

Upaya kepala sekolah SD Plus Nurul Hikmah Pamekasan dalam mengembangkan budaya sekolah yang efektif tidak lepas dari perannya sebagai pemimpin sekolah yaitu mempengaruhi bawahannya untuk mengikuti intruksi dan arahannya dalam melaksanakan tugas penyelenggaraan sekolah dalam rangka mengembangkan dan memajukan sekolah, khususnya dalam mengembangkan budaya sekolah efektif.

Dalam mengembangkan budaya sekolah efektif, kepala sekolah SD Plus Nurul Hikmah Pamekasan telah menerapkan fungsinya sebagai educator, manajer, administrator, supervisor, leader, inovator, dan motivator dengan baik. Peran kepala sekolah ini sesuai dengan syarat kepala sekolah yang efektif menurut kementrian pendidikan dan kebudayaan dalam perspektif kebijakan pendidikan nasional (Depdiknas, 2006) bahwa kepala sekolah dikatakan mempunyai efektifitas kepemimpinan yang tinggi apabila kepala sekolah mampu melaksanakan perannya sebagai educator, manajer, administrator dan supervisor (EMAS). Dalam perkembangan selanjutnya, sesuai dengan kebutuhan masyarakat dan perkembangan zaman, maka kepala sekolah juga harus mampu berperan sebagai leader, innovator dan motivator di sekolahnya.

Peran kepala sekolah ini juga sejalan dengan pandangan Mulyasa (2009: 98) yang menyatakan bahwa dalam paradigma baru manajemen pendidikan, kepala sekolah sedikitnya harus mampu berfungsi sebagai educator, manajer, administrator, supervisor, leader, inovator, dan motivator (EMASLIM).

Pertama, peran sebagai edukator. Kepala sekolah sebagai edukator berperan dalam mengembangkan budaya sekolah efektif. sebagai pendidik, kepala sekolah tergolong pendidik yang disiplin baik dari kehadiran dan juga dari kelengkapan administrasi pembelajaran untuk memberikan contoh dan teladan bagi guru yang lain. Selain itu, sebagai pendidik kepala sekolah sudah menerapkan kurikulum 2013 yang lebih menekankan pada pembiasaan, praktek, dan penanaman akhlak melalui integrasi nilai-nilai karakter dalam pembelajaran. Hal tersebut dapat mendukung pembentukan budaya sekolah yang efektif.

Sebagai edukator, kepala sekolah juga selalu berupaya meningkatkan kualitas pembelajaran dengan meningkatkan profesionalisme guru dalam pembelajaran diantaranya dengan mengikutsertakan guru dalam sejumlah pelatihan dan workshop yang salah satunya pelatihan dan workshop yang dilakukan oleh KPI (Kualita Pendidikan Indonesia). Hal ini sejalan dengan pandangan Mulayasa (2009:100) yang menyatakan bahwa upaya yang dilakukan kepala sekolah sebagai edukator dalam meningkatkan kinerja tenaga kependidikan diataranya adalah mengikutsertakan para guru dalam penataran untuk menambah wawasan para guru, berusaha menggerakkan tim evaluasi hasil belajar peserta didik dan menggunakan waktu belajar secara efektif di sekolah.

Kedua, peran sebagai manajer. Kepala sekolah sebagai manajer berperan dalam mengembangkan budaya sekolah efektif melalui beberapa program kebijakan pembiasaan nilai-nilai positif, seperti budaya 5S, budaya baca, budaya jujur dan lain 
sebagainya. Program ini disusun kepala sekolah melalui tahapan manajerial yang baik mulai dari perencanaan, pengorganisasian, pelaksanaan dan monitoring evaluasi. Peran kepala sekolah sebagai manajer ini sesuai dengan pernyataan Mulyasa (2009:103) bahwa manajemen pada hakekatnya merupakan suatu proses merencanakan, mengorganisasikan, melaksanakan, memimpin dan mengendalikan usaha para anggota organisasi serta mendayagunakan seluruh sumber daya organisasi dalam rangka mencapai tujuan yang telah ditetapkan.

Untuk melihat sejauh mana ketercapaian tujuan, kepala sekolah selalu melakukan evaluasi terhadap kinerja dan pelaksanaan program sekolah secara rutin baik dilaksanakan dalam forum rapat mingguan maupun bulanan, baik rapat yang sifatnya formal maupun non formal (situasional). Evaluasi ini dilaksanakan untuk mereviuw seberapa jauh capaian dan seberapa besar kesenjangan yang terjadi di lapangan untuk mewujudkan perubahanperubahan menuju kondisi sekolah yang lebih baik. Kepala sekolah juga selalu menggunakan assessment dan analisis dalam membuat program ke bijakan khususnya dalam membangun budaya sekolah yang efektif, sehingga budaya sekolah tersebut dikembangkan sesuai dengan kebutuhan, kultur sekolah dan menjadi nilai plus bagi sekolah.

Ketiga, peran sebagai administrator. Kepala sekolah SD Plus Nurul Hikmah Pamekasan sebagai administrator berupaya untuk melaksanakan tugas-tugas administrasi dengan baik sehingga terbangun budaya tertib administratif. Kemampuan kepala sekolah dalam mengelola administrasi tercermin dalam pengelolaan administrasi yang tertib di sekolah, misalnya kepala sekolah menyusun EDS, RKS di awal tahun dan bentuk-bentuk tugas administrasi lainnya seperti kepala sekolah mengharuskan semua guru untuk melengkapi perangkat pembelajaran mulai dari kalender pendidikan, prota, prosem, silabus, RPP dan lain sebagainya. Kepala sekolah juga melakukan penertiban administrasi kelas dan sebagainya.

Dalam melaksanakan tugas administrasi kepala sekolah tidak bekerja sendiri, tetpai melakukan pemberdayaan dengan membentuk lima wakil kepala sekolah sebagai kepala urusan (Ka.Ur) yaitu kepala urusan tata usaha, kepala urusan kurikulum, kepala urusan kesiswaan, kepala urusan keuangan, kepala urusan sarana dan prasarana dan kepala urusan hubungan masyarakat (Humas).

Keempat, peran sebagai supervisor. Kepala sekolah sebagai supervisor melakukan beberapa upaya dalam mengembangkan budaya sekolah yang efektif. Upaya tersebut diantaranya kepala sekolah melakukan supervisi secara rutin untuk mengetahui sejauh mana guru dalam mengajar, salah satu teknik supervisi yang digunakan adalah supervisi kunjungan kelas. tujuan dari supervisi ini adalah melakukan pembinaan terhadap guru untuk mewujudkan guru yang professional. Selain itu, kepala sekolah juga seringkali mendatangkan supervisor ahli yang memang expert dalam bidangnya. Misalnya supervisi guru al-Qur'an yang disupervisi oleh seorang ahli dalam bidang al-Qur'an. $\mathrm{Hal}$ ini sejalan dengan pernyataan Mulyasa (2009:111) bahwa supervisi sesungguhnya dapat dilaksanakan oleh kepala sekolah yang berperan sebagai supervisor, tetapi dalam sistem organisasi pendidikan modern diperlukan supervisor khusus yang lebih independent, dan dapat meningkatkan objektivitas dalam pembinaan dan pelaksanaan tugasnya.

Kelima, peran sebagai leader atau pemimpin. Sebagai leader kepala sekolah memiliki peran yang besar dalam mengembangkan budaya sekolah efektif. salah satu perannya adalah penerapan gaya kepemimpinan kepala sekolah yang cenderung partisipatif membuat kepala sekolah disegani di kalangan guru dan warga sekolah. Selain itu, sebagai leader kepala sekolah berupaya membangun komunikasi dan hubungan yang harmonis bagi semua warga sekolah sehingga terbangun budaya kerja sama yang baik di lingkungan sekolah dan menumbuhkan loyalitas yang tinggi diantara warga sekolah.

Keenam, peran sebagai inovator. Sebagai inovator, kepala sekolah SD Plus Nurul Hikmah Pamekasan mengagas beberapa program pengembangan budaya sekolah, misalnya kepala sekolah membuat program untuk membudayakan kejujuran 
dengan bentuk program mentoring akhlak. Dalam program ini, peserta didik di upayakan untuk berkata jujur terkait apa yang telah dilakukan baik itu berbentuk pelanggaran maupun kebaikan. selain itu, terdapat beberapa program lain yang tergolong baru sebagai hasil pembaharuan kepala sekolah. Hal ini mendukung pendapat Mulyasa (2009:119) yang menyatakan bahwa kepala sekolah sebagai innovator harus mampu mencari, menemukan, melaksanakan berbagai pembaharuan di sekolah.

Ketujuh, peran sebagai motivator. Sebagai motivator, kepala sekolah berperan dalam mengembangkan budaya sekolah efektif. diantara perannya adalah dengan selalu memberikan dorongan terhadap bawahan untuk meningkatkan tanggung jawabanya dalam tugas masing-masing. Kepala sekolah SD Plus Nurul Hikmah Pamekasan selalu memberikan motivasi misalnya yang sering dilakukan kepala sekolah adalah ketika forum rapat guru.

Kepala sekolah SD Plus Nurul Hikmah Pamekasan sebagai motivator yang selalu memberikan motivasi dan inspirasi bagi guru, peserta didik, dan juga bagi karyawan yang ada di lingkungan sekolah untuk selalu bersama-sama membangun budaya sekolah yang unggul dan efektif yang salah satunya adalah dengan membangun budaya kompetisi di semua warga sekolah untuk saling berkompetisi untuk berprestasi dan menjadi yang terbaik. kompetisi di kalangan guru misalnya, kepala sekolah menunjuk guru favorite dan teladan dengan memberikan sistem reward. Adapun kompetisi di kalangan peserta didik, kepala sekolah membuat satu kelas unggulan di setiap tingkatan sebagai media bagi peserta didik untuk selalu berkompetisi masuk di kelas unggulan tersebut. Secara umum, bentuk motivasi kepala sekolah adalah berupa kata-kata, dorongan, pekikan semangat, maupun berupa penghargaan (reward) baik di kalangan guru maupun peserta didik.

\section{Upaya Kepala Sekolah dalam Mengembangkan Budaya Sekolah yang Efektif.}

Berdasarkan hasil penelitian, kepala sekolah SD Plus Nurul Hikmah Pamekasan melakukan beberapa upaya dalam mengembangkan budaya sekolah yang efektif. Beberapa upaya tersebut adalah membangun hubungan yang harmonis diantara semua warga sekolah, meningkatkan keamanan sekolah dan mengembangkan lingkungan sekolah yang kondusif untuk belajar.

Upaya kepala sekolah ini sejalan dengan pandangan Is Yuli Gunawan yang dikutip dalam (http://www.p4tksb-jogja.com) yang memaparkan tiga bidang tugas utama kepala sekolah untuk membangun kondisi sekolah yang kondusif yaitu:

\section{Mengembangkan hubungan yang harmonis antar komponen sekolah}

Salah satu upaya yang dilakukan kepala sekolah SD Plus Nurul Hikmah Pamekasan dalam upaya mengembangkan budaya sekolah yang efektif adalah mengembangkan hubungan yang harmonis dengan seluruh komponen sekolah. Upaya ini mendukung pernyataan Pidarta (2015:77) yang mengemukakan bahwa ciri-ciri iklim sekolah yang positif adalah adanya hubungan yang harmonis dan akrab antara personel sekolah, adanya hubungan kekeluargaan, adanya saling percaya diantara para gru yang menyebabkan suasana menjadi nyaman, para guru memiliki sifat antusiasme dalam bekerja, adanya komitmen yang tinggi para guru terhadap sekolahnya, dan para guru merasa bangga terhadap sekolah.

Upaya kepemimpinan kepala sekolah dalam mengembangkan hubungan yang harmonis ini dinilai oleh Mulyasa (2012:19) sebagai salah satu kriteria kepemimpinan kepala sekolah yang efektif, yaitu mampu menjalin hubungan yang harmonis dengan masyarakat sehingga dapat melibatkan mereka secara aktif dalam rangka mewujudkan visi dan misi sekolah serta tujuan sekolah, selain itu kepala sekolah dapat bekerja secara kolaboratif dengan tim manajemen sekolah.

Untuk mewujudkan hubungan yang harmonis kepala sekolah SD Plus Nurul Hikmah Pamekasan melakukan beberapa cara diantaranya, Intensitas Komunikasi. Intensitas komunikasi dilakukan oleh kepala sekolah melalui berbagai pendekatan, baik formal maupun non formal. Pendekatan formal misalnya melalui rapat-rapat rutin bersama guru baik mingguan maupun 
bulanan, rapat bersama wali santri, rapat dua bulanan bersama komite sekolah, adapun pendekatan non formal dilakukan melalui istighosah, khataman al-Qur'an, WA group, bakar-bakar, kultum dan sejenisnya. Intensitas komunikasi yang dilakukan kepala sekolah tidak hanya dengan guru tetapi dengan seluruh komponen sekolah termasuk komite, wali murid dan masyarakat secara umum. Hal ini berpengaruh pada hubungan yang harmonis di lingkungan sekolah dan dapat meningkatkan partisipasi terhadap pengembangan sekolah yang lebih efektif.

Intensitas komunikasi dengan berbagai pendekatan ini menunjukkan bahwa kepala sekolah SD Plus Nurul Hikmah Pamekasan adalah kepala sekolah yang efektif sebagaimana pernyataan Lashway (dalam Stronge, et.all., 2008:106) yang menyatakan bahwa kepala sekolah yang efektif harus memiliki keterampilan memimpin dan ilmu untuk menyatukan semua pemangku kepentingan dalam mencapai tujuan bersama.

Keterampilan komunikasi yang baik juga merupakan bagian dari keterampilan hubungan manusia (human skill) yang harus dikuasai seorang kepala sekolah dalam menjalankan tugasnya sebagai kepala sekolah sebagaimana pernyataan Wahjosumidjo (2002: 97) yang menjelaskan bahwa tugas kepala sekolah adalah bekerja dengan dan melalui orang lain. Agar dapat bekerja dengan dan melalui orang lain, kepala sekolah harus berperilaku sebagai saluran komunikasi di lingkungan sekolah meningkatkan partisipasi dengan kerja sama/kolaborasi, Upaya lain dilakukan kepala sekolah SD Plus Nurul Hikmah Pamekasan untuk mengembangkan hubungan yang harmonis adalah dengan meningkatkan partisipasi warga sekolah. Peningkatan partisipasi ini dilakukan dengan beberapa cara, diantaranya melalui pelibatan warga sekolah dalam program kebijakan sekolah, gaya kepemimpinan partisipatif kepala sekolah, dan sifat kepala sekolah yang komunikatif juga menjadi senjata kepala sekolah dalam mengembangkan partisipasi warga sekolah.

Upaya kepala sekolah SD Plus Nurul Hikmah Pamekasan tersebut dapat meningkatkan hubungan warga sekolah semakin harmonis. Keharmonisan ini akan membentuk kerjasama yang baik dan kolaborasi yang apik di antara warga sekolah sehingga terwujud budaya sekolah yang kondusif dan efektif. Upaya kepala sekolah dalam meningkatkan partisipasi dan kerjasama dilakukan dengan semua warga sekolah, baik di lingkungan sekolah maupun di luar lingkungan sekolah. Perihal ini sejalan dengan pendapat Stronge, et.all., (2008:19-20) yang menyatakan bahwa:

Dalam menciptakan lingkungan
pembelajar yang positif dan aman,
pemimpin sekolah yang efektif
melibatkan seluruh komunitas sekolah,
diantaranya siswa, staf, orang tua
siswa, dan anggota komunitas
sekolah... usaha-usaha membentuk
hubungan interpersonal dengan
komunitas tersebut akan sangat
menguntungkan dalam membangun
lingkungan sekolah yang positif dan
produktif.

\section{Mengembangkan Keamanan Sekolah}

Upaya lain yang dilakukan kepala sekolah SD Plus Nurul Hikmah Pamekasan dalam upaya mengembangkan budaya sekolah yang efektif adalah mengembangkan keamanan sekolah baik secara psikologis, fisik, sosial, dan keamanan kultural. Hal ini dilakukan kepala sekolah untuk menjamin keamanan warga sekolah, dengan demikian semua warga sekolah menjadi betah dan senang untuk sekolah di SD Plus Nurul Hikmah Pamekasan.

Upaya kepala sekolah ini sudah tepat, mengingat sekolah adalah tempat interaksi dan kumpulan paserta didik yang mempunyai banyak perbedaan yang kadang kala dapat menimbulkan gesekan antara yang satu dengan yang lainnya. Christensen merilis data dari National school and staffing survey (SASS) di Amerika Serikat yang menemukan bahwa tantangan-tantanngan terhadap tata tertib dan keamanan sekolah selalu ada pada sekolah jenis apapun juga, apakah itu sekolah umum, sekolah pemerintah ataupun sekolah swasta (Stronge, et.all., 2008:88).

Upaya pengembangan keamanan oleh kepala sekolah ini juga sebagai usaha preventif terhadap hal-hal yang tidak diinginkan. Upaya ini dibenarkan oleh Barrios et al., sebagaimana dikutip Stronge, 
et.all., (2008:89) yang menyatakan bahwa pencegahan terjadinya kecelakaan di sekolah adalah tugas pemimpin sekolah baik secara hukum maupun etika.

Beberapa upaya telah dilakukan kepala sekolah SD Plus Nurul Hikmah Pamekassan dalam megembangkan keamanan sekolah diantaranya melalui peraturan tertulis, pakta integritas guru, KKS (kartu kendali siswa), fasilitas penunjang keamanan, pemberdayaan satpam, pengadaan kotak saran, dan juga slogan-slogan melalui banner, plakat dan lain sebagainya. Selain itu, upaya kepala sekolah dalam mengembangkan keamanan sekolah juga melalui pengembangan budaya $5 S$ (senyum, sapa, salam, sopan, santun).

Upaya kepala sekolah dalam mengembangkan keamanan sekolah sudah melaksanakan tanggung jawabnya sebagai kepala sekolah sebagaimana dikemukakan Stronge, et.all., (2008:89) yang menyatakan bahwa kepala sekolah diberi tanggung jawab menjaga keamanan semua pihak yang berada dalam lingkungan sekolah, termasuk staf dan pengunjung. Pencegahan terjadinya kecelakaan di sekolah adalah tugas pemimpin sekolah baik secara hukum maupun secara etika. Memelihara lingkungan pembelajaran yang aman yang bebas dari bahaya dan gangguan memiliki implikasi lebih dari iklim positif sekolah. kepala sekolah harus proaktif menangani dan mengawasi isu-isu keamanan berlandaskan hokum yang berlaku. Diantara kasus kecelakaan siswa, $58 \%$ dilaporkan terjadi karena faktor kurangnya pengawasan yang tepat.

\section{Mengembangkan Lingkungan Sekolah yang Kondusif.}

Berdasarkan hasil penelitian, kepala sekolah SD Plus Nurul Hikmah Pamekasan juga melakuan beberapa upaya lain dalam mengembangkan budaya sekolah yang efektif yaitu dengan mengembangkan lingkungan dan suasana yang kondusif. Berikut beberapa upaya kepala sekolah dalam mengembangkan lingkungan dan suasana sekolah yang kondusif.

\section{Mengembangkan lingkungan sekolah yang agamis/budaya agamis \\ Pengembangan lingkungan yang agamis/budaya agamis di SD Plus Nurul}

Hikmah Pamekasan dilakukan dengan menanamkan perilaku atau tatakrama yang tersistematis dalam pengamalan agamanya masing-masing sehingga terbentuk kepribadian dan sikap yang baik (Akhlaqul Karimah). Dengan penanaman akhlakul karimah ini, akan berimplikasi pada terciptanya linkungan yang kondusif dilakukan dengan bentuk peraturan, posterisasi dan pembiasaan, diantaranya ialah mengaji al-Quran di pagi hari selama 1 jam, berdo'a sebelum dan sesudah pembelajaran, sholat dhuhur dan ashar berjema'ah, anjuran untuk berbusana sopan, program tahfidz surat pendek.

\section{Mengembangkan lingkungan fisik sekolah yang bersih, indah, dan nyaman \\ Upaya lain kepala sekolah SD Plus} Nurul Hikmah Pamekasan dalam mengembangkan lingkungan sekolah yang kondusif juga dilakukan dengan membuat lingkungan akademis yang bersih, nyaman, lingkungan belajar yang indah.

Untuk merealisasikannya, kepala sekolah menerapkan aturan dalam menjaga kebersihan lingkungan sekolah diantaranya penjadwalan piket kelas, selain itu kepala sekolah memberdayakan tiga staf kebersihan yang bertugas menjaga kebersihan di seluruh lingkungan sekolah, mentoring akhlak, serta kepala sekolah juga selalu memberikan motivasi-motivasi dalam berbagai kesempatan, baik dalam rapat, kultum, dan melalui media WA. Selain itu, untuk membangun sekolah yang bersih dan rapi, kepala sekolah melakukan posterisasi berupa slogan, plakat, dan juga banner yang menyerukan tentang kebesihan.

\section{Mengembangkan lingkungan akademik yang kondusif}

Upaya kepala sekolah SD Plus Nurul Hikmah Pamekasan dalam mengembangkan lingkungan belajar yang kondusif dalam arti pembelajaran di kelas selama ini masih sebatas memberikan peraturan kelas dan motivasi terhadap para guru untuk lebih meningkatkan pengajarannya, hal tersebut dilakukan untuk mengupayakan terciptanya lingkungan kelas yang nyaman bagi siswa dalam belajar. Adapun ditinjau dari sisi idealitas kelas, sebagaimana ungkapan kepala sekolah sebelumnya bahwa SD Plus Nurul Hikmah 
belum termasuk ideal disebabkan tidak seimbangnya antara kapasitas peserta didik dan ukuran kelas sebagaimana termaktub dalam Permendikbud No. 23 Tahun 2013 yang memberi batasan jumlah siswa tidak melebihi 32 dalam satu kelas.

Permasalahan terkait kapasitas peserta didik dengan jumlah rombel yang tidak seimbang ini sedikit berpengaruh terhadap lingkungan pembelajaran yang kondusif, hal ini terjadi disebabkan terus meningkatnya peminat yang mendaftar setiap tahunnya. Peningkatan jumlah peminat ini tidak bisa diimbangi dengan pembangunan fisik sekolah yang masih cenderung lamban. Untuk mengurai permasalahan ini, kepala sekolah sudah beberapa kali melakukan terobosan salah satunya dengan menetapkan kouta yang ideal dengan keadaan dan jumlah kelas.

\section{Peningkatan Kedisiplinan Siswa}

Peningkatan kedisiplinan juga menjadi upaya kepala sekolah SD Plus Nurul Hikmah Pamekasan dalam mengembangkan lingkungan sekolah yang kondusif. Peningkatan kedisiplinan dilakukan melalui pemantauan, pemodelan, pengadaan fingerprint baik untuk guru dan peserta didik, sistem reward and punishment, dan juga posterisasi yang berisi pesan-pesan kedisiplinan. Upaya-upaya tersebut membawa peningkatan yang cukup berarti dalam hal kedisiplinan di SD Plus Nurul Hikmah Pamekasan, namun perlu beberapa upaya yang lebih intensif dari kepala sekolah terutama dalam kedisiplinan guru.

Upaya kepala sekolah SD Plus Nurul Hikmah Pamekasan ini sejalan dengan pandangan Hurlock (1970:70) yang mengemukakan bahwa unsur kedisiplinan yang harus dimiliki institusi dalam mendidik anak untuk berprilaku sesuai standar yang diharapkan ialah peraturan tata tertib, penghargaan (reward), hukuman (punishment), dan konsistensi (istiqomah). Hal yang hampir sama dikemukakan Sugiarti (2015:176) bahwa Disiplin sangatlah penting dalam proses pendidikan, sekolah harus memiliki sebuah aturan tertulis sebagai landasan kedisiplinan (aturan tata tertib yang mengikat) yang harus diikuti serta diterapkan oleh setiap siswa dan seluruh warga sekolah.

\section{Budaya Kompetisi}

Upaya kepala sekolah yang lain dalam mengembangkan lingkungan kondusif adalah membangun budaya kompetisi, budaya kompetisi ini dibangun dalam rangka untuk memberikan motivasi dan dorongan belajar yang kuat dan berprestasi. Budaya kompetisi di kalangan murid sudah terbangun salah satunya melalui kelas unggulan di setiap tingkatan. Selain itu, kepala sekolah juga membuat program bimbingan berprestasi khusus mapel MIPA yang diambil dari kelas tiga sampai kelas enam, Pembimbingan ini juga berfungsi sebagai pembibitan kegiatan lomba-lomba seperti OSN dan lainnya, hal itu dilakukan dalam rangka menjaga dan meningkatkan citra sekolah. Pengembangan budaya kompetisi ini secara tidak langsung akan berimplikasi terhadap pembentukan lingkungan belajar yang kondusif.

Budaya kompetisi yang dibangun kepala sekolah dengan berbagai upaya tersebut mempunyai korelasi positif dengan pencapaian prestasi. Hal ini sesuai dengan pandangan David McClella sebagai mana dikutip dalam (https://sites.google.com: Para 3) yang menyatakan bahwa jika suatu masyarakat diberikan rangsangan dan pelatihan untuk berprestasi maka hasilnya akan lebih baik dibandingkan dengan kelompok masyarakat yang tidak ditumbuhkan budaya kompetisi dan prestasinya.

Dari beberapa data hasil penelitian dan temuan di lapangan serta ditinjau dari beberapa teori, dapat disimpulkan bahwa upaya kepala sekolah dalam mengembangkan budaya sekolah melalui pengembangan hubungan yang harmonis, pengembangan keamanan di lingkungan sekolah dan pengembangan lingkungan yang kondusif secara perlahan dapat meningkatkan keefektifan di SD Plus Nurul Hikmah Pamekasan.

\section{KESIMPULAN}

Gaya kepemimpinan kepala sekolah SD Plus Nurul Hikmah Pamekasan tidak hanya menerapkan salah satu gaya kepemimpinan tertentu, tapi kondisional sesuai kondisi dan situasi yang dihadapi. Kepala sekolah menerapkan gaya partisipatif misalnya, hal ini tercermin dalam partisipasi aktif kepala sekolah. Kepala sekolah juga menerapkan 
gaya delegatif melalui pemberdayaan staf dan bawahan dalam beberapa kepala urusan (Ka.Ur). Kepala sekolah juga bersikap otoriter dalam dalam situasi yang mendesak dan sifatnya penting untuk segara dilaksanakan atau dieksekusi.

Peran kepemimpinan kepala sekolah dalam mengembangkan budaya sekolah efektif adalah menerapkan fungsi kepala sekolah sebagai educator, manajer, administrator, supervisor, leader, inovator, dan motivator dengan baik.

Upaya-upaya kepala sekolah SD Plus Nurul Hikmah Pamekasan dalam mengembangkan budaya sekolah yang efektif adalah sebagai berikut: Mengembangkan hubungan yang harmonis diantara semua warga sekolah, yang dilakukan dengan intensitas komunikasi dan peningkatan partisipasi; mengembangkan keamanan sekolah yang dilakukan dengan peraturan tertulis, pakta integritas, KKS (Kartu Kendali Siswa), piket guru, fasilitas penunjang keamanan, dan pemberdayaan petugas keamanan, posterisasi pesan keamanan; Mengembangkan lingkungan sekolah yang kondusif untuk belajar yang dilakukan dengan mengembangkan lingkungan sekolah yang agamis/budaya agamis, mengembangkan lingkungan fisik sekolah yang bersih, indah, dan nyaman, mengembangkan lingkungan akademik yang kondusif, peningkatan kedisiplinan, mengembangkan budaya kompetisi untuk berprestasi.

\section{SARAN}

Berdasarkan simpulan hasil penelitian dan pembahasan yang telah dipaparkan maka terdapat beberapa saran yang dapat dikemukakan penulis sebagai berikut: Kepala sekolah diharapkan untuk selalu konsisten dalam menjaga, mempertahankan dan improvisasi gaya kepemimpinannya untuk menjadi lebih baik; kepala sekolah SD Plus Nurul Hikmah Pamekasan diharapkan untuk selalu mempertahankan dan meningkatkan perannya dalam mengembangkan budaya sekolah untuk mewujudkan sekolah yang efektif; Kepala sekolah SD Plus Nurul Hikmah Pamekasan senantiasa menjaga hubungan yang akrab dengan semua warga sekolah dan menjaga dan mempertahankan serta lebih meningkatkan lagi keamanan di lingkungan sekolah, baik keamanan fisik, maupun psikis; Kepala sekolah SD Plus Nurul Hikmah Pamekasan senantiasa menjaga lingkungan sekolah untuk lebih kondusif sebagai tempat belajar, dan lebih memperhatikan pembangunan fisik berupa ruang kelas.

\section{DAFTAR RUJUKAN}

Chin, J. M. (2007). Meta-analysis of Transformational School Leadership Effects on School Outcomes in Taiwan and the USA. 8(2), 166-177.

Ekosiswoyo, R. (n.d.). Kepemimpinan kepala sekolah yang efektif kunci pencapaian kualitas pendidikan. 76-82.

Gunawan, I., Administrasi, J., Fakultas, P., Pendidikan, I., \& Malang, U. N. (n.d.). ORGANISASI GURU SEKOLAH DASAR NEGERI A . 59-80.

Hasmayati, Y., Masalah, A. L. B., \& Selatan, K. (2011). MOTIVASI KERJA TERHADAP KOMPETENSI GURU( Studi pada Jurusan Bisnis dan Manajemen Sekolah Menengah Kejuruan Negeri dan Swasta di Kabupaten Sumedang ) Abstrak. 9(18), 78-86.

Hauge, T. E., \& Norenes, S. O. (2014). School leadership and educational change: Tools and practices in shared school leadership development. (123), 357-376. https://doi.org/10.1007/s10833-0149228-y

Hasibuan dan Malayu. 2007. Manajemen Sumber Daya Manusia. Cet. Ke-IX. Jakarta: PT. Bumi Aksara.

Hurlock, b. Elizabeth. 1978. Perkembangan anak. Jakarta:

Erlangga.https://sites.google.com/site/g oodartikel/motivasi/membangunbudaya-berkompetisi-dan-berprestasidi-sekolah, 12:33 selasa 18 april 2017

K. Yin, Robert. 2000. Studi Kasus Desain dan Metode. Jakarta: PT Raja Grafindo Persada

Leo, U., \& Wickenberg, P. (2013). Professional norms in school leadership: Change efforts in 
implementation of education for sustainable development. 403-422. https://doi.org/10.1007/s10833-0139207-8

Moleong, Lexy. 2011. Metode Penelitian Kualitatif.Cet Ke-29. Bandung: Remaja Rosdakarya.

Mulyasa, H.E. 2013. Manajemen dan Kepemimpinan Kepala Sekolah. Cet ke3. Jakarta: Bumi Aksara.

Nasution, W. N. (2015). Kepemimpinan pendidikan di sekolah. 22(1), 66-86.

$\mathrm{Ng}$, P. T. (2012). An examination of school leadership in Singapore through the lens of the Fourth Way. 27-34. https://doi.org/10.1007/s10671-0119114-9

Pidarta, Made. 2000. Landasan Pendidikan. Jakarta: Rineka Cipta.

Pidarta, Made. 2015. Wawasan Pendidikan. Cet. Ke-2. Surabaya: UNESA Press.

Purwanti, S. (2013). PERAN KEPEMIMPINAN KEPALA SEKOLAH DALAM MENINGKATKAN DISIPLIN KERJA GURU DAN. 1(1), 210-224.

Rivai, Veithzal. 2004. Kepemimpinan dan Perilaku Organisasi. Jakarta: Raja Grafindo Persada.

Sagala, Sayful. 2010. Manajemen Strategik dalam Peningkatan Mutu Pendidikan. Bandung: Alfabeta.

Stronge. James. H; Richard. Holly. B; Catano. Nancy. 2013. Kualitas Kepala. Sekolah yang Efektif. Terj. Siti Mahyuni. Jakarta: PT Indeks

Sugiarti. 2015. Faktor-Faktor Strategis Pendukung Kinerja Sekolah Di Smk Kota Surakarta. Jurnal Varia Pendidikan. Vol. 27. No. 2 Desember 2015: 174-182

Sugiyono. 2015. Metode Penelitian Pendidikan. Cet. Ke-11. Bandung: Alfabeta.

Somprach, K., Ngang, K., \& Popoonsak, P. (2017). The relationship between school leadership and education schools. Educational Research for Policy and Practice, 16(2), 157-175. https://doi.org/10.1007/s10671-016-
9206-7

Sudarya, Y., Suratno, T., \& Indonesia, U. P. (2002). Dimensi kepemimpinan kepala sekolah.

Sudharta, V. A., Mujiati, M., Rosidah, A., Gunawan, I., \& Malang, U. N. (n.d.).

Sun, J., Przybylski, R., \& Johnson, B. J. (2016). A review of research on teachers ' use of student data: from the perspective of school leadership. 5-33. https://doi.org/10.1007/s11092-0169238-9

Surjana, A. (n.d.). Efektivitas Pengelolaan Kelas.

Thoha, Miftah. 2006. Kepemimpinan dalam Manajemen. Jakarta: PT. Raja Graafindo Persada.

Wahjosumidjo. 2002. Kepemimpinan Kepala Sekolah Tinjauan Teoritik dan Permasalahannya. Jakarta: Rajawali Pers (02), 68-81.

Tabularasa, J., \& Unimed, P. P. S. (2011). JURNAL TABULARASA PPS UNIMED Vol.8 No.1, Juni 2011. 8(1), 61-72.

Walker, A., Truong, T. D., Kong, H., \& Tri, Q. (2015). Confucian Values and Vietnamese School Leadership. 1-6. https://doi.org/10.1007/978-981-287532-7

Yuen, A. H. K., Lee, M. W., \& Law, N. (2009). School leadership and teachers 'pedagogical orientations in Hong Kong: A comparative perspective. 381396. https://doi.org/10.1007/s10639009-9091-2 